\title{
Analysis and Design of Box Girder and T-Beam Bridge Superstructure - A Comparative Study
}

\author{
Rao Jang Sher ${ }^{1 a}$, Muhammad Irfan-ul-Hassan ${ }^{1 b}$, Muhammad Talha Ghafoor ${ }^{1 c}$, \\ Atif Qayyum ${ }^{1 d}$
}

\section{RECEIVED ON 21.12.2018, ACCEPTED ON 19.02.2019}

\begin{abstract}
Bridges are the most important component of transportation system of any country due to their ability of accelerating the development of the nation. Design of bridge highly depends on its function, nature of soil strata where it is constructed and the material used to construct it. Extensive growth of population and traffic leads to many changes in the use and development of different types of bridges. Box and T-beam girders are most commonly used superstructure in case of bridges. In this research work, analysis and design of box and $T$ beam girder has been performed using SAP2000 in order to find out the most suitable type of bridge superstructure. The main objective of this study is to compare the structural behavior, optimization of materials used in each component and cost comparison of box and $T$ beam girder bridge. Previous research in this regard is based upon working stress method but this research follows limit state design. Detailed comparison shows that box girder is more suitable as compared to $\mathrm{T}$ beam girder even for shorter span in terms of structural stability and cost efficiency.
\end{abstract}

Keywords: Box Girder, T Beam Girder, SAP2000, Limit State Design, Cost Comparison.

\section{INTRODUCTION}

$\mathrm{B}$ ridges play an important role in development because they have potential to reduce the transportation cost by saving the time. That's why the demand of bridge structures has sharply increased these days. Due to considerable increase in bridges demand in mass transit systems, low cost bridge construction is one of the key challenges of current era. It is vital for civil engineer to fulfill the requirements of both safety and economy simultaneously. Owning to its aesthetic and structural importance, bridge superstructure has major influence on overall cost of bridges. The basic function of bridge superstructure is to permit and facilitate continuous smooth passage of traffic over it and distribute the forces to the substructure safely. Box and $\mathrm{T}$ beam girders are considered as the most suitable options for short and intermediate span of bridges. Previous researches in this regard are limited to utility of one of the available design methods. These studies rule out the comparative study in term of structural and economic pros and cons. Thus the non-availability of comparative data of bridge structure using strength design method motivated us to carry out this research.

This study emphasizes on comparison between box and $\mathrm{T}$ beam girder with respect to structural stability and economy. That is, provided with the two kind of girders having equal span length, it is required to select the stable and economical one. Box girder is a bridge type in which beam comprises of shape of hollow box and lies between the piers or abutment (Fig.1). Adopting the use of box girder has a key advantage of availability of more torsional stiffness and strength as compared to any other shape [1]. Box girder won acceptance readily all over the world due to better

${ }^{1}$ Department of Civil Engineering, University of Engineering and Technology, Lahore, Pakistan.

Email: aengr rao@hotmail.com, birfanulhassan@uet.edu.pk (Corresponding Author),

cmuhammadtalhaghafoor@gmail.com, datifkashmiri123@gmail.com

This is an open access article published by Mehran University of Engineering and Technology, Jamshoro under CC BY 4.0 International License. 
structural efficiency, stability and cost effectiveness. Furthermore, the maintenance of box girder is found easier due to accessible interior space. $T$ beam bridge is a reinforced concrete bridge consisting of floor slab which is monolithic with supporting beams so that cross section resembles a series of $\mathrm{T}$ beams (Fig. 2).

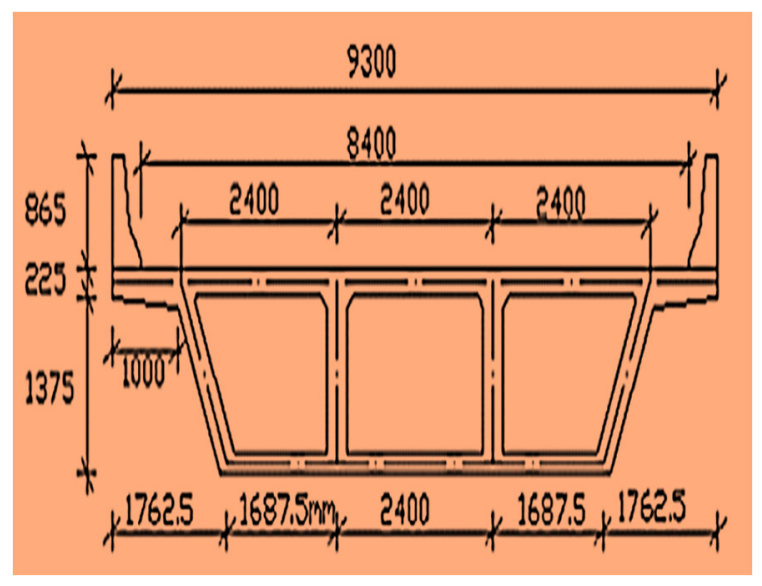

FIG. 1: CROSS SECTION OF SELECTED BOX GIRDER SUPERSTRUCTURE

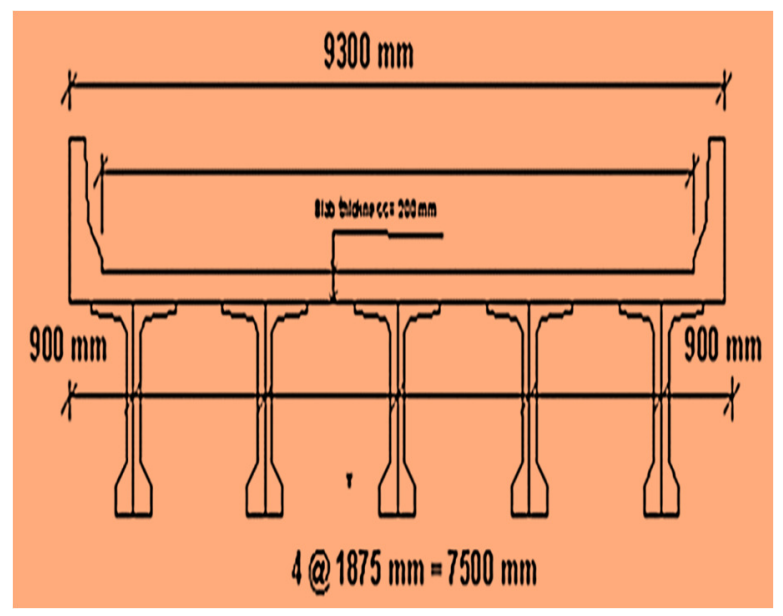

FIG. 2. CROSS SECTION OF SELECTED T BEAM GIRDER BRIDGE

Principally, $\mathrm{T}$ beam girder bridges are preferred up to 25 meters long span and beyond this these are neglected due to lesser capacity to resist the applied forces. The superstructure of $\mathrm{T}$ beam bridge generally includes but not limited to deck slab, longitudinal girders, cross girders, barriers and abutments. Important things regarding selection of superstructure of bridges are safety and economy. Safety accommodates all kinds of loads within service limits. Economy of the bridge includes the initial cost, maintenance cost and replacement cost. Although aesthetic requirements do not demand compulsion of consideration, yet the simplicity of design and pleasure of vision must be ensured while adopting the type of superstructure. Numerous other factors are to be taken into account while selecting the type of bridge superstructure. These include type of flyover, nature of river or stream, nature of available soil strata, amount and type of traffic and economy. The main objective of this research is to compare the structural behavior and cost of box and $\mathrm{T}$ beam girder for selected span of fix length. The design method used in this study is Load and Resistance factor design (LRFD). This study includes comparison between box and $\mathrm{T}$ beam girder bridge for normal flexural and shear resistance, deflection under dead and live load, optimum use of materials and economy.

\subsection{List of Symbols}

$\eta \quad$ Coefficient of value 0.95 according to AASHTO Bridge specifications

$\gamma_{\mathrm{i}} \quad$ Load Modifier

$\theta_{i} \quad$ Angle of channel turn to horizontal

$\mu \quad$ Friction Factor

$\gamma_{p} \quad$ Load factor for permanent loading

DC Dead load of structural components

DW Dead load of wearing surface and utilities

LL Vehicle live load

IM Dynamic load allowance

A Area of cross section

$\mathbf{Y}_{\mathbf{b}}$ Distance of neutral axis from the bottom of girder

$\mathbf{Y}_{\mathbf{t g}} \quad$ Distance of neural axis from the top of girder

INA Moment of inertia bout neutral axis

$\mathbf{S}_{\mathbf{b}} \quad$ Bottom section modulus

$\mathbf{S}_{\mathrm{tg}} \quad$ Top section modulus

$\mathbf{W}_{\text {s }} \quad$ Load due to wearing surface

S Center to center spacing between girders

AASHTO American Association of State Highway and Transportation Officials

\section{LITERATURE REVIEW}

The study of related literature provides overview of different methodologies adopted for analysis and design of prestressed box and $\mathrm{T}$ beam girder [2-4]. A comprehensive study about analyzing the bridge Mehran University Research Journal of Engineering and Technology, vol. 39, No. 3, July 2020 [p-1SSN: 0254-7821, e-1SSN: 2413-7219] 
inventory in the central and southeastern United States shows that approximately $95 \%$ of the bridges are multi-span simply supported girder bridges and continuous girder bridges. Majority of these bridges has either reinforced concrete, prestressed concrete or steel girders with reinforced concrete decks [5]. The most important stage in conceptual design of short and medium span highway bridges is to select the superstructure [6]. These attributes regarding the design of bridge superstructure are based on economy, construction time, durability, aesthetics, maintenance considerations and designer preference. An improper selection of girder type may reduce the quality of structure and productivity. Superstructure mainly represents the $70 \%$ of the total structural cost [7]. Comparison of box and $\mathrm{T}$ beam girder shows that $\mathrm{T}$ beam girder is cost effective for shorter span. It should be noted that bridges having span length up to $25 \mathrm{~m}$ are generally considered as short span bridges. Beyond this length are medium and long span bridges. With an increase in span length, box girder becomes more economical as compared to $\mathrm{T}$ beam girder. After comparison of I section and box section, researchers concluded that box girder is expensive for span of 16.3 $\mathrm{m}$ whereas for span of $31.4 \mathrm{~m}$ box girder is economical [8]. Pre-stressed concrete section gives more flexural and shear resistance as compared to simple reinforced concrete members for large span bridges. This is the reason pre-stressed concrete sections are considered more economical as compared to reinforced concrete members [9]. Life cycle of prestressed concrete member is more as compared to reinforced concrete and steel structures [10]. Service life of prestressed I section is approximately 17 years more as compared to box girder beam [11]. A lot of research has been carried out regarding comparison of girder bridge cost with respect of span length and life cycle. Numerous researchers studied different spans of I girder bridge to compare the initial cost of prestressed concrete or steel girder and found that pre-stressed concrete girder is economical for larger span as compared to steel girder. With an increased span length, prestressed concrete girder appears to be more economical as compared to steel girder but for span up to 15 meters, steel girder is cheaper [12-13]. It has been studied that trapezoidal section pre-stressed concrete girder is winning popularity due to better strength and appearance as compared to any other section [14]. The design of bridge structure consists of two stages. The first stage is conceptual design in which overall form of the structure is decided upon, while the second stage focuses on more detailed structural analysis [15-16]. Thorough review and study of literature indicates various studies aiming at solution of the problems related to selection of superstructure using working stress method. In working stress method, only service loads are taken into account and material strength is not fully utilized. One of the most commonly used forms of superstructure in concrete bridges is precast girders with cast-in-situ slab. For such type of bridges, span length to depth ratio is usually kept as 20 for simply supported span and 25 for continuous spans. Most of the studies discussed herein deal with allowable stress design method. Now a days, limit state design method is more preferred [17] because it has more safe design criteria. This method uses factored loads and full material strength is considered for design purpose. This results in rational design with respect to strength and economy. Therefore, comparison between two different girders is done using load and resistance factor design method in this study. Previous comparative studies of box and $\mathrm{T}$ beam bridges do not provide estimated quantities and corresponding costs of components of bridge superstructure. Hence this research is carried out to address all these issues related to material and cost estimation besides structural behavior.

\section{METHODOLOGY}

Bridge superstructure was designed and analyzed using SAP2000 for $25 \mathrm{~m}$ long simply supported span, with deck slab width of $9.3 \mathrm{~m}$ and $2.5 \mathrm{~m}$ wide two lane carriage way for both type of bridge superstructure shown in Fig. 1 and Fig. 2 respectively. Detailed manual design calculations were also performed. General features for both type of bridge superstructure are summarized in Table 1. Standard traffic loadings according to AASHTO LRFD code provision were used for analysis [18]. Dead Loads were calculated for the defined dimensions of various components of superstructure i.e. wearing coarse, deck slab, concrete barrier shown Fig. 3 and Fig. 4 respectively. Whereas live load was applied as HL-93 truck, lane and tandem loading as represented in Fig.5. Load combination and application followed the standards from section 3 of LRFD bridge design manual [18]. The general load Mehran University Research Journal of Engineering and Technology, Vol. 39, No. 3, July 2020 [p-ISSN: 0254-7821, e-ISSN: 2413-7219] 
combination equation used in this study is shown in equation 1

$\eta \Sigma \gamma_{\mathrm{i}} \theta_{\mathrm{i}}=\mu \times\left(=\gamma_{\mathrm{p}} \mathrm{DC}+\gamma_{\mathrm{p}} \mathrm{DW}+1.75 \times(\mathrm{LL}+\right.$ IM))

TABLE 1: GENERAL FEATURES OF SELECTED BOX AND T BEAM GIRDER BRIDGE

\begin{tabular}{|l|c|c|}
\hline \multicolumn{1}{|c|}{ Description } & Box Girder & $\begin{array}{c}\text { T Beam } \\
\text { Girder }\end{array}$ \\
\hline $\begin{array}{l}\text { Span Length between } \\
\text { Abutments }\end{array}$ & $25000 \mathrm{~mm}$ & $25000 \mathrm{~mm}$ \\
\hline No. of Traffic Lines & 2 & 2 \\
\hline $\begin{array}{l}\text { Bridge width from } \\
\text { curb to curb }\end{array}$ & $9300 \mathrm{~mm}$ & $9300 \mathrm{~mm}$ \\
\hline No. of Girders/Web & 4 & 5 \\
\hline $\begin{array}{l}\text { C/C. spacing of } \\
\text { girders }\end{array}$ & $2400 \mathrm{~mm}$ & $1875 \mathrm{~mm}$ \\
\hline Slab Thickness & $200 \mathrm{~mm}$ & $200 \mathrm{~mm}$ \\
\hline $\begin{array}{l}\text { Compressive } \\
\text { Strength of Concrete } \\
\text { for slab }\end{array}$ & $35 \mathrm{MPa}$ & $21 \mathrm{MPa}$ \\
\hline $\begin{array}{l}\text { Compressive } \\
\text { Strength of Concrete } \\
\text { for Girder }\end{array}$ & $420 \mathrm{MPa}$ & $420 \mathrm{MPa}$ \\
\hline $\begin{array}{l}\text { Yield Strength of } \\
\text { Reinforcing Steel }\end{array}$ & $1860 \mathrm{MPa}$ & $1860 \mathrm{MPa}$ \\
\hline $\begin{array}{l}\text { Strength of Pre- } \\
\text { stressing Strand }\end{array}$ & $35 \mathrm{MPa}$ \\
\hline \multicolumn{2}{|c|}{} & \\
\hline
\end{tabular}

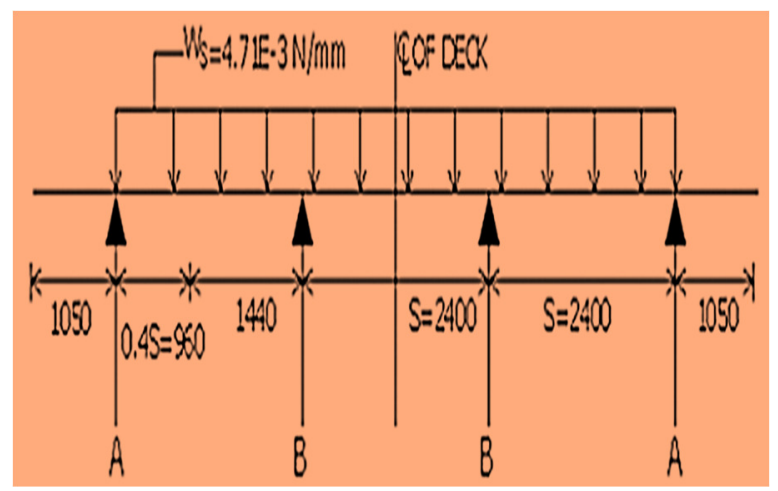

FIG. 3: TYPICAL DEAD LOAD PATTERN DUE TO DECK SLAB IN CASE OF BOX GIRDER BRIDGE

Influence Line Diagrams (ILDs) for application of live load at different locations were drawn and critical i.e. maximum influencing loading arrangement is considered as applied live load. As live loadings dominate the total load in order to resist flexural stresses, T- beam section in considered more suitable as compared to I section [19]. That's why comparison of box girder was carried out with T-beam girder.
There was little difference between material properties for both type of bridges. For box girder bridge compressive strength of concrete used was $35 \mathrm{MPa}$ and it remained obviously same for both slab and girder listed in Table 1. While for $\mathrm{T}$ beam girder bridge compressive strength of concrete used in reinforced concrete slab was $21 \mathrm{MPa}$ and $35 \mathrm{MPa}$ for concrete used in girder. Yield strength of reinforcing steel for both type of bridges remains same and its value was $420 \mathrm{MPa}$ shows in Table 1. Strength of prestressing steel was $1860 \mathrm{MPa}$ and it remains same for both type of girders.

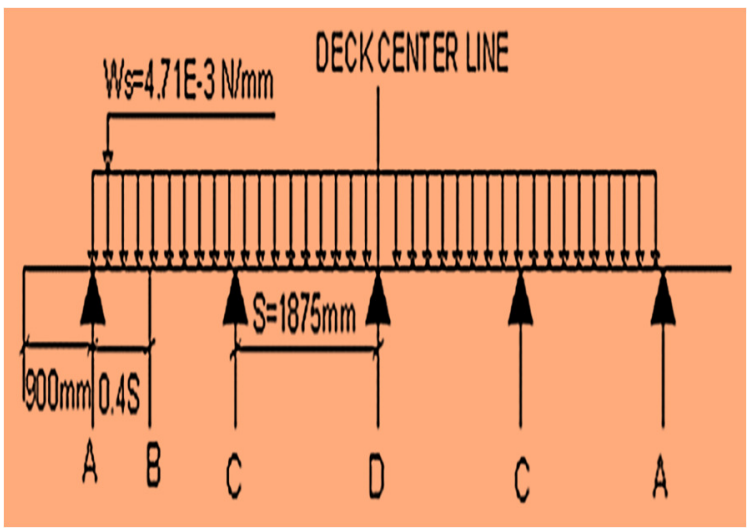

FIG. 4: TYPICAL DEAD LOAD PATTERN DUE TO DECK SLAB IN CASE OF T BEAM GIRDER

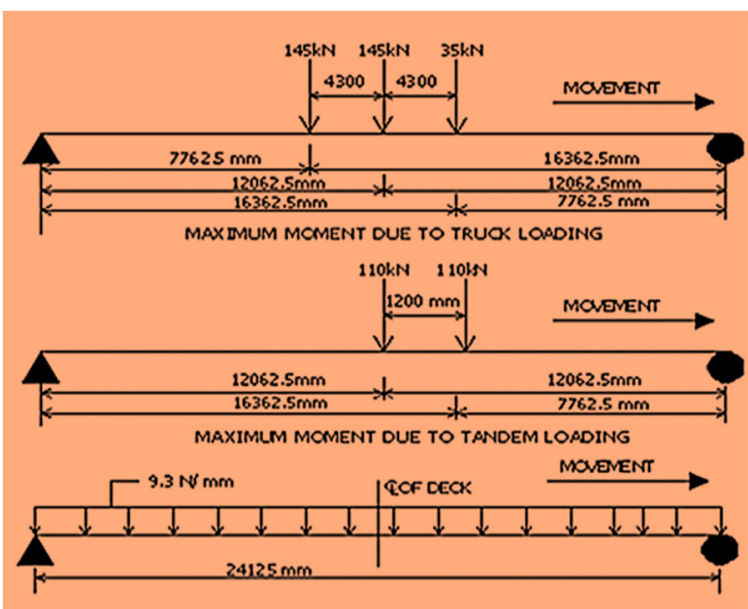

FIG. 5: TYPICAL LIVE LOAD PATTERN FOR BOTH BOX AND T BEAM GIRDER

Geometrical properties of selected sections are listed in Table 2. From Table 2 it is evident that overall moment of inertia and section modulus values were more for box girder as compared to $\mathrm{T}$ beam girder. So, stiffness was more in case of box girder. Detailed standard box and $\mathrm{T}$ - beam selected sections are shown 
in Fig. 1 and Fig. 6 respectively. Cross sectional view of selected $\mathrm{T}$ beam girder bridge is represented in Fig. 2. The dimensions of selected standard sections follow code provisions [18]. Geometrical properties such as deck thickness, soffit slab thickness, web thickness for box girder whereas web thickness, top and bottom flange thicknesses and flange width of T- beam section are decided based upon chapter 5 of LRFD bridge design manual [18]. The structural depth of girder including slab thickness is decided on the basis of chapter 2 of standard specifications [18]. Generally, web spacing for box girder and girder spacing for Tbeam varies from $2100 \mathrm{~mm}$ to $2700 \mathrm{~mm}$ based on the standard practice [20]. $75 \mathrm{~mm}$ thick bituminous layer is placed curb to curb. Fillets of $100 \times 100 \mathrm{~mm}$ were provided between deck slab and web of Box Girder whereas no fillet is to be provided between web and soffit slab [19]. Diaphragms of $300 \mathrm{~mm}$ width were provided at both ends and mid sections. Effective span for analysis and design was $24125 \mathrm{~mm}$ which was based upon standard requirements for both types.

TABLE 2. GEOMETRICAL PROPERTIES OF SELECTED BOX AND T BEAM GIRDER BRIDGE

\begin{tabular}{|c|c|c|}
\hline Description & $\begin{array}{c}\text { Box Girder } \\
\text { (Web) }\end{array}$ & $\begin{array}{c}\text { T Beam Section } \\
\text { (Grouted section } \\
\text { at end })\end{array}$ \\
\hline $\mathrm{A}\left(\mathrm{mm}^{2}\right)$ & 1105000 & 452871 \\
\hline $\mathrm{Y}_{\mathrm{b}}(\mathrm{mm})$ & 858.2 & 760 \\
\hline $\mathrm{Y}_{\mathrm{tg}}(\mathrm{mm})$ & 741.8 & 640 \\
\hline $\mathrm{I}_{\mathrm{NA}}\left(\mathrm{mm}^{4}\right)$ & $4.75 \mathrm{E} 11$ & $11 \mathrm{E} 10$ \\
\hline $\mathrm{S}_{\mathrm{b}}\left(\mathrm{mm}^{3}\right)$ & $554 \mathrm{E} 6$ & $146 \mathrm{E} 6$ \\
\hline $\mathrm{S}_{\mathrm{tb}}\left(\mathrm{mm}^{3}\right)$ & $640 \mathrm{E} 6$ & $173 \mathrm{E} 6$ \\
\hline
\end{tabular}

Effective span for analysis and design was $24125 \mathrm{~mm}$ which was based upon standard requirements for both types. Effective flange width for interior girder and exterior girders in case of T-beam was $1875 \mathrm{~mm}$ and $1890 \mathrm{~mm}$ respectively. Interestingly these values for box girder were quite different i.e. $2400 \mathrm{~mm}$ and 2250 $\mathrm{mm}$. Values for number of design lanes and multiple presence factor were taken as 2 and 1 respectively from section 3 . The deck slab was analyzed for dead and live load with the help of analysis software SAP2000. Maximum values of negative moments were then reduced as per chapter 4 of LRFD bridge design specification. These reduced moments were then used for reinforcement design.

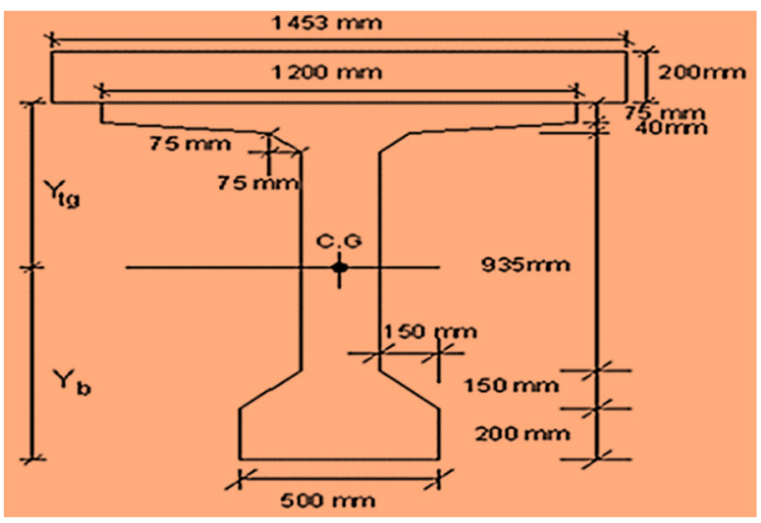

FIG. 6: T BEAM COMPOSITE SELECTED GIRDER SECTION

After satisfying our selected sections based on stresses and deflections induced by dead and live loads, shear and moment were compared at critical exterior and interior points of the structural components including deck slab and barrier. Design reinforcement was compared with maximum and minimum allowable range standardized in section 5 of AASHTO LRFD specifications [18]. Secondary reinforcement was provided to accommodate temperature and shrinkage stresses. Ductility check and moment capacity is verified if capacity was more than design moment. The reinforcing steel was increased otherwise so that moment capacity was more than design moment. After satisfaction of moment capacity stress limit states were checked according to chapter 5 of LRFD specification [18]. Prestressing was done by selecting the type of post-tensioned girder and is prestressed by considering low relaxation $12.70 \mathrm{~mm}$ seven wire strands. Choice of prestressing tendons was based on either the concrete stress limits at service loads or the sectional strength under the factored load. Prestressing losses were calculated and stress limit states were verified based on these losses. Considering the effect of prestressing, deflections were calculated and controlled. Deflection values were compared for both type of girder bridges. Structural behavior of both type of bridges was compared. Finally, detailed BOQs were prepared in order to compare the material usage and cost required for both type of bridges. Step wise summary of design procedure is shown in Fig.7. 


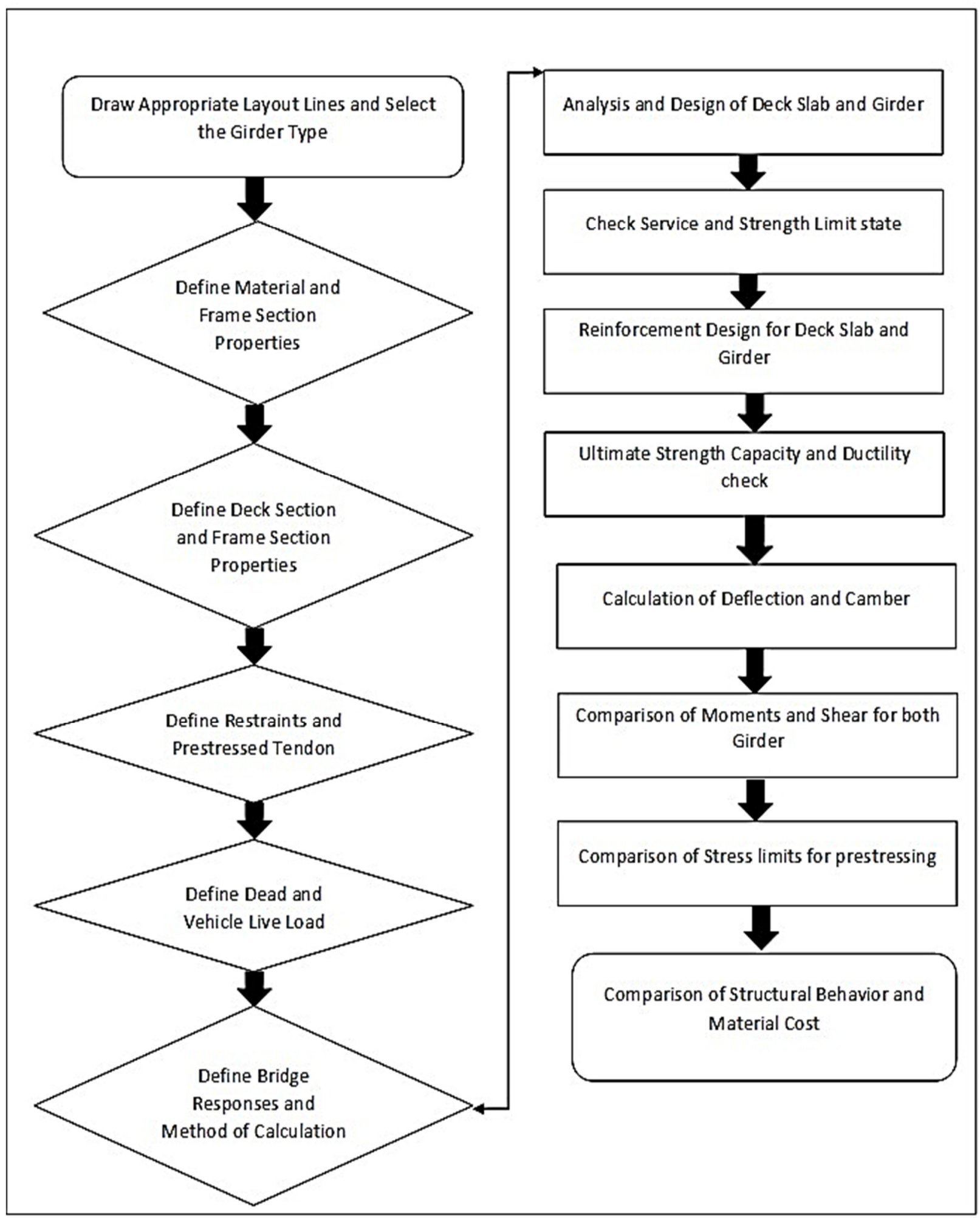

FIG. 7: STEPS FOR ANALYSIS AND DESIGN OF BOX AND T BEAM GIRDER BRIDGE 


\section{RESULTS AND DISCUSSIONS}

Analysis and design of both type of girder was done using SAP2000 in accordance with AASHTO LRFD design as well as by manual calculation. Since HL-93 provides critical loading for prestressed concrete bridges, the same is selected for our research [21]. After meeting the requirements of safety, service limit states and strength limits states comparison between structural behavior and economy was carried out. Previous researches show that $\mathrm{T}$ beam girder is economical as compared to box girder for shorter span by using working stress method [4]. Herein by using LRFD method box girder shows better results with respect to strength and cost as compared to $T$ beam girder even for shorter span. Maximum value of moment and shear due to all types of dead load is calculated for both girders and critical is observed in case of box girder as compared to $\mathrm{T}$ beam girder as shown in Table 3. Maximum positive moment due to lane load is critical for T-beam girder as shown in Table 3. Similarly, due to live load, maximum shear value for exterior girder is larger in case of box girder listed in Table 3. Comparison of maximum moment and maximum shear for slab design of box and $\mathrm{T}$ beam girders are graphically represented in Fig. 8 and Fig.9 respectively. Design negative moment at exterior girder is $52.5 \mathrm{KN}-\mathrm{m} / \mathrm{m}$ in case of box girder and 40 $\mathrm{KN}-\mathrm{m} / \mathrm{m}$ in case of $\mathrm{T}$ beam represented by Fig. 10. All the values of design moments are also shown in Fig. 10. Reduced negative and positive moment for reinforcement design is $42 \mathrm{KN}-\mathrm{m} / \mathrm{m}$ for box girder while $18 \mathrm{KN}-\mathrm{m} / \mathrm{m}$ and $36 \mathrm{KN}-\mathrm{m} / \mathrm{m}$ for $\mathrm{T}$ beam girder respectively. Based on the design moments, both type of girder are designed and prestressing tendon is calculated. Choice of prestressing tendon is done based on concrete stress limits at service loads and sectional strength under factored load. For T-beam girder parabolic profile is selected and based on stresses area of prestressing strand required is 3258 $\mathrm{mm}^{2}$. Stress limit state at end and mid-section at the time of prestressing and after losses for $\mathrm{T}$ beam girder is summarized in Table 4. For box girder area of prestressing required is $2786 \mathrm{~mm}^{2}$. For box girder stress limit states for prestressing at bottom and top shows in Table 5. After the computational and comparative satisfaction of design forces and stresses for both type of girder next objective is to compare the economy of the selected bridges. Complete bill of quantities (BOQ) for box and $\mathrm{T}$ beam girder bridge are prepared for the comparison of cost as shown in Table 6 and 7. BOQ explain the step wise procedure briefly for the calculation of quantities, so one can easily understand the step wise procedure for the calculation of unit rates through these tables. Different quantities have different units of measurement based on their market availability like concrete is measured in cubic meter $\left(\mathrm{m}^{3}\right)$ but steel rate is available per $100 \mathrm{~kg}$. In case of box girder bridge quantity of concrete required is $125.36 \mathrm{~m}^{3}$ shown in Table 8 . Out of this $125.36 \mathrm{~m}^{3}$, girder consumes $41.268 \mathrm{~m}^{3}$ concrete. Whereas for $\mathrm{T}$ beam girder bridge superstructure, $82.497 \mathrm{~m}^{3}$ out of total $147.13 \mathrm{~m}^{3}$ is required for girder only. This makes it evident that material consumption and consequently the cost is greatly influenced by bridge girder. Quantity of reinforcing steel required for box girder bridge is $18537 \mathrm{~kg}$ described in Table 8. From this total quantity, $37.25 \%$ is required for deck slab. Remaining $35.15 \%$ is required for girder, $9.45 \%$ for barrier and $18.15 \%$ is used in bottom slab. For T beam girder bridge amount of reinforcing steel other than prestressing steel required is $17111 \mathrm{~kg}$ listed in Table 8. From this total amount, $57.5 \%$ of steel is required in girder. Remaining amount of steel required in barrier is $6.4 \%, 26.35 \%$ for deck slab and $9.75 \%$ for diaphragm. From the above discussion it is evident that girder act as governing factor in deciding the strength and economy. Box girder require less concrete by $21.75 \mathrm{~m}^{3}$ but require excess steel by 1426 $\mathrm{kg}$ as shown in Table 8. For the satisfaction of stresses and deflection number of prestressing cables required are more in case of $\mathrm{T}$ beam girder shown in Table 8. So overall, there is difference of $646 \mathrm{~kg}$ steel for prestressing between these two types of girders listed in Table 8.

Cost comparison is done based on market rate system made by the finance department of government of Pakistan. The rate includes labour, materials, cutting, bending, placing and contractors' profit. As the number of lanes are same for both girders the cost of bitumen required is same as evident from Fig. 11. Overall comparison of cost for both type of girders are shown in tabular form in Table 9. Cost comparison of concrete, reinforcing steel and prestressing steel for both type of bridge girder is shown in Fig. 11. 
TABLE 3. FORCE EFFECTS FOR SLAB DESIGN FOR BOX AND T BEAM GIRDER (UNIT STRIP)

\begin{tabular}{|c|c|c|c|c|c|c|c|c|}
\hline \multirow{3}{*}{ Description } & \multicolumn{4}{|c|}{$\begin{array}{l}\text { Maximum Moment } \\
(\mathrm{N}-\mathrm{mm} / \mathrm{mm})\end{array}$} & \multicolumn{4}{|c|}{$\begin{array}{l}\text { Maximum Shear } \\
(\mathrm{N} / \mathrm{mm})\end{array}$} \\
\hline & \multicolumn{2}{|c|}{$\begin{array}{l}\text { Exterior } \\
\text { Support }\end{array}$} & \multicolumn{2}{|c|}{$\begin{array}{l}\text { Interior } \\
\text { Support }\end{array}$} & \multicolumn{2}{|c|}{$\begin{array}{l}\text { Exterior } \\
\text { Support }\end{array}$} & \multicolumn{2}{|c|}{$\begin{array}{l}\text { Interior } \\
\text { Support }\end{array}$} \\
\hline & $\begin{array}{c}\text { Box } \\
\text { Girder }\end{array}$ & $\begin{array}{c}\mathrm{T} \\
\text { beam } \\
\text { Girder }\end{array}$ & $\begin{array}{l}\text { Box } \\
\text { Girder }\end{array}$ & $\begin{array}{l}\text { T beam } \\
\text { Girder }\end{array}$ & $\begin{array}{c}\text { Box } \\
\text { Girder }\end{array}$ & $\begin{array}{l}\text { T beam } \\
\text { Girder }\end{array}$ & $\begin{array}{l}\text { Box } \\
\text { Girder }\end{array}$ & $\begin{array}{l}\text { T beam } \\
\text { Girder }\end{array}$ \\
\hline $\begin{array}{l}\text { Self-weight of } \\
\text { deck slab }\end{array}$ & 0 & 0 & -2702 & -1762 & 4.5 & 3.78 & 12.4 & 10.07 \\
\hline $\begin{array}{c}\text { Cantilever } \\
\text { overhang slab }\end{array}$ & -3407 & -2147 & 673 & 594 & 8.19 & 6.23 & -1.71 & 1.93 \\
\hline Barrier & -5388 & -4482 & 1065 & 1241 & 8.73 & 9.09 & -2.7 & 4.04 \\
\hline $\begin{array}{l}\text { Wearing } \\
\text { surface }\end{array}$ & -300 & -168 & -895 & 574 & 3.02 & 2.09 & 3.96 & 3.4 \\
\hline $\begin{array}{c}\text { One lane live } \\
\text { load for max. } \\
\text { positive } \\
\text { moment }\end{array}$ & - & - & -14962 & -16154 & 20 & 22.25 & 67 & 68.72 \\
\hline $\begin{array}{l}\text { Two lane live } \\
\text { load for max. } \\
\text { positive } \\
\text { moment }\end{array}$ & - & - & -11118 & -12303 & 17 & 19.16 & 53 & 53.5 \\
\hline $\begin{array}{l}\text { Live load for } \\
\text { max. negative } \\
\text { moment }\end{array}$ & - & - & -20731 & -16950 & - & - & - & - \\
\hline $\begin{array}{l}\text { Live load for } \\
\text { max. reaction } \\
\text { at exterior } \\
\text { girder }\end{array}$ & - & - & - & - & 87 & 80.35 & - & - \\
\hline $\begin{array}{l}\text { Live load on } \\
\text { overhang for } \\
\text { max. negative } \\
\text { moment }\end{array}$ & -18800 & -14500 & - & - & - & - & - & - \\
\hline
\end{tabular}

TABLE 4. T-BEAM GIRDER STRESS LIMITS FOR PRESTRESSING

\begin{tabular}{|c|c|c|c|c|}
\hline \multirow{2}{*}{ Loading Stage } & \multicolumn{2}{|c|}{ Stress at End (MPa) } & \multicolumn{2}{c|}{ Stress at Mid (MPa) } \\
\cline { 2 - 5 } & At Bottom & At Top & At Bottom & At Top \\
\hline $\begin{array}{c}\text { At Transfer of } \\
\text { prestressing force }\end{array}$ & $-5.67<-15.5$ & $-5.67<1.28$ & $-15.6<-15.5$ & $-1.89<1.28$ \\
\hline $\begin{array}{c}\text { Stresses after total } \\
\text { losses }\end{array}$ & $-4.68<2.96$ & $-4.68<-15.8$ & $1.61<2.96$ & $-10.2<15.8$ \\
\hline
\end{tabular}

TABLE 5. BOX GIRDER STRESS LIMITS FOR PRESTRESSING

\begin{tabular}{|c|c|c|c|c|}
\hline Loading Stage & \multicolumn{2}{|c|}{ Stress at Bottom (MPa) } & \multicolumn{2}{c|}{ Stress at Top (MPa) } \\
\cline { 2 - 5 } & actual & allowable & actual & $>0$ \\
\hline $\begin{array}{c}\text { At Transfer of } \\
\text { prestressing force }\end{array}$ & 3.92 & $<14.3$ & 2.96 & $<15.75$ \\
\hline $\begin{array}{c}\text { Stresses after total } \\
\text { losses }\end{array}$ & 0.33 & $>0$ & 4.48 & \\
\hline
\end{tabular}




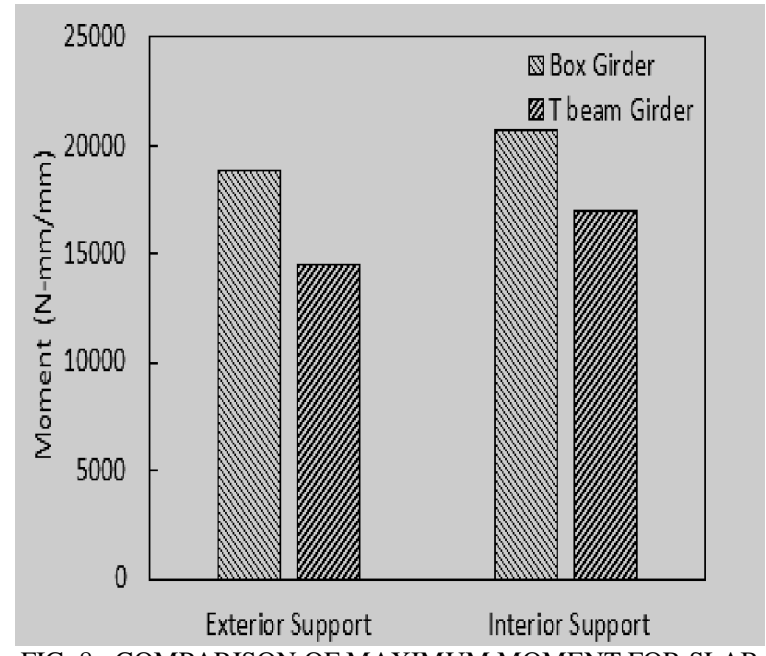

FIG. 8: COMPARISON OF MAXIMUM MOMENT FOR SLAB DESIGN FOR BOX AND T BEAM GIRDER

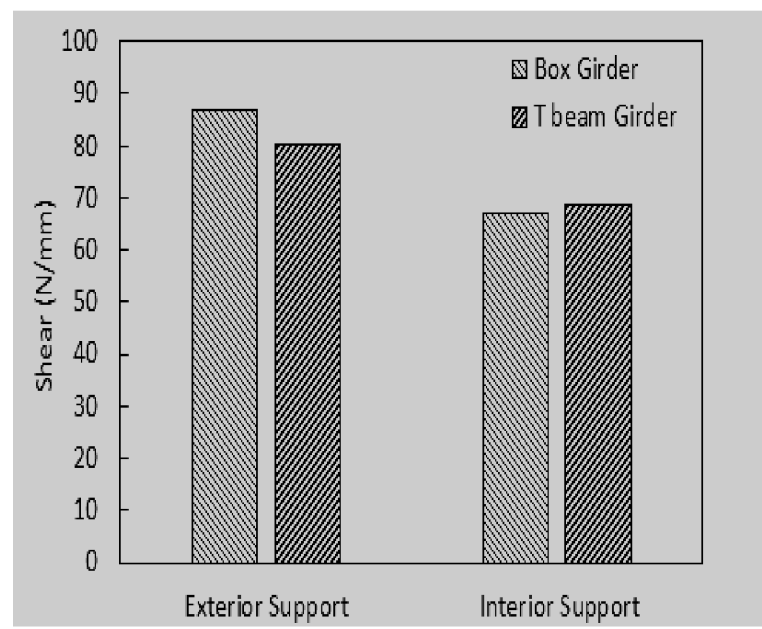

FIG. 9: COMPARISON OF MAXIMUM SHEAR FOR SLAB DESIGN FOR BOX AND T BEAM GIRDER

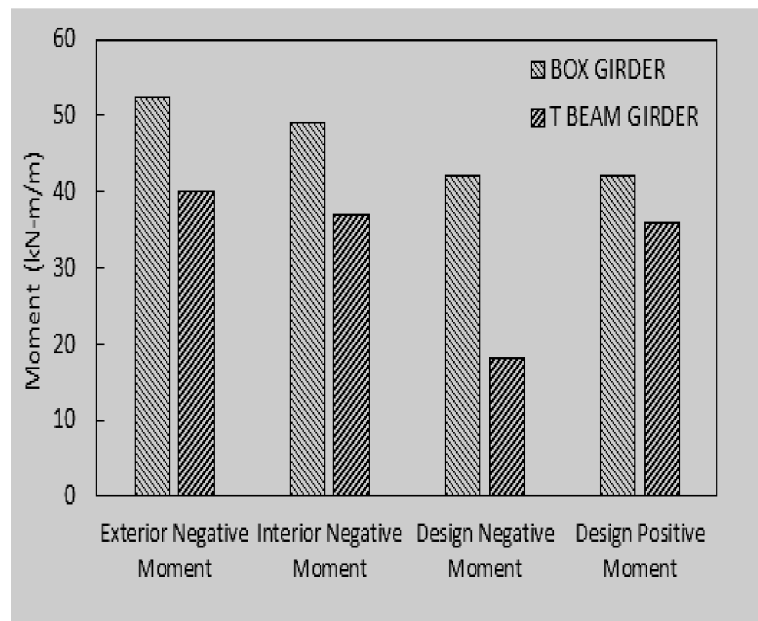

FIG. 10: COMPARISON OF DESIGN MOMENT FOR BOX AND T BEAM GIRDER BRIDGE
Cost comparison is done based on market rate system made by the finance department of government of Pakistan. The rate include labour, materials, cutting, bending, placing and contractors' profit. As the number of lanes are same for both girders the cost of bitumen required is same as evident from Fig. 11. Overall comparison of cost for both type of girders are shown in tabular form in Table 9. Cost comparison of concrete, reinforcing steel and prestressing steel for both type of bridge girder is shown in Fig. 11.

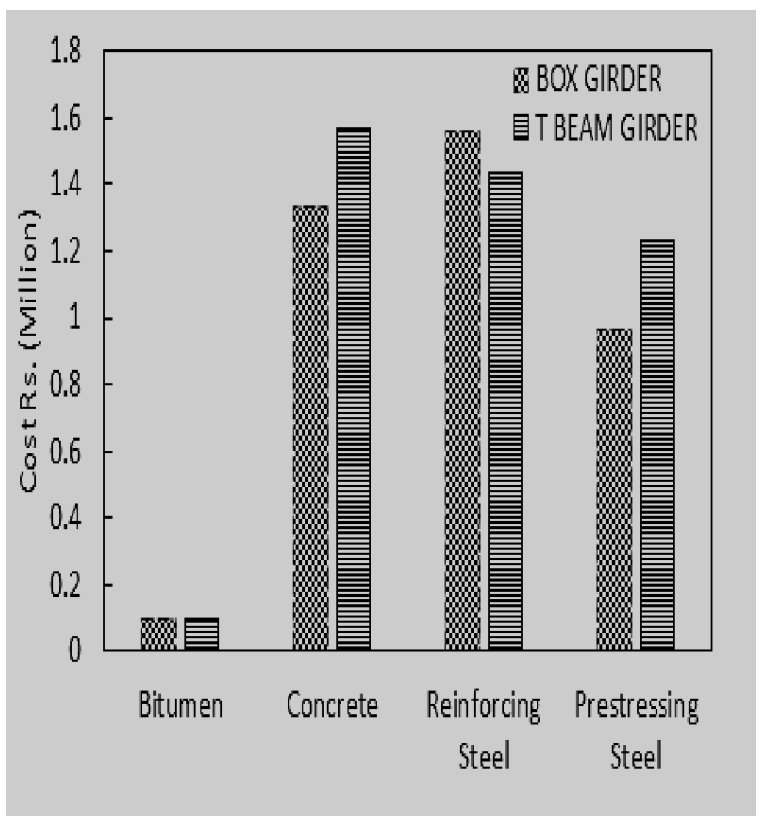

FIG. 11: COST COMPARISON BETWEEN BOX AND T BEAMGIRDER BRIDGE IN MILLIONS

Box girder is expensive w.r.t to reinforcing steel by amount of 0.12 million represented by Fig. 11. T beam girder is more expensive for prestressing reinforcing steel by 0.26 million shown in Fig. 11. The percentage difference of both type of girders is shown in Table 9. Overall, there is a huge difference of cost for both type of girder for same span. So, it means that geometry as well the selected girder type plays an important role with respect to strength and economy. Box girder is cheaper than $\mathrm{T}$ beam girder for a span of $25 \mathrm{~m}$ by amount of 0.37 million as shown in Fig. 11. The results projected for $1 \mathrm{Km}$ long bridge showed a cost difference of 15 million between box and $\mathrm{T}$ beam girder bridge. Whereas design lanes play less significant role in cost variation. 
TABLE 6. BILL OF QUANTITIES FOR BOX GIRDER BRIDGE

\begin{tabular}{|c|c|c|c|c|c|c|}
\hline Sr. No. & Description & No. & $\mathrm{L}(\mathrm{m})$ & $\mathrm{B}(\mathrm{m})$ & $\mathrm{H}(\mathrm{m})$ & Quantity \\
\hline 1 & $\begin{array}{c}\text { Bituminous wearing } \\
\text { surface }\end{array}$ & 1 & 24.975 & 8.4 & - & $209.79 \mathrm{~m}^{2}$ \\
\hline 2 & Concrete $35 \mathrm{MPa}$ & 2 & 24.957 & 0.22 & 0.865 & $9.506 \mathrm{~m}^{3}$ \\
\hline \multirow{5}{*}{ a } & \multirow{4}{*}{$\begin{array}{l}\text { Barrier on both side } \\
\text { of deck slab }\end{array}$} & 2 & 24.957 & 0.55 & 0.535 & $0.668 \mathrm{~m}^{3}$ \\
\hline & & 2 & 24.957 & $0.18 / 2$ & 0.255 & $1.146 \mathrm{~m}^{3}$ \\
\hline & & 2 & 24.957 & 0.05 & 0.33 & $0.824 \mathrm{~m}^{3}$ \\
\hline & & 2 & 24.957 & 0.18 & 0.075 & $0.674 \mathrm{~m}^{3}$ \\
\hline & Total & \multicolumn{4}{|c|}{-} & $12.818 \mathrm{~m}^{3}$ \\
\hline \multirow{7}{*}{$\mathrm{b}$} & Overhang slab & 2 & 24.975 & 0.95 & $(0.225+0.3) / 2$ & $12.456 \mathrm{~m}^{3}$ \\
\hline & Top slab & 1 & 24.975 & 7.2 & 0.2 & $35.964 \mathrm{~m}^{3}$ \\
\hline & Bottom slab & 1 & 24.975 & 6.1 & 0.15 & $22.852 \mathrm{~m}^{3}$ \\
\hline & Outer Web & 2 & 24.975 & 0.3 & 1.454 & $21.788 \mathrm{~m}^{3}$ \\
\hline & Interior web & 2 & 24.975 & 0.3 & 1.25 & $18.731 \mathrm{~m}^{3}$ \\
\hline & Top fillet & 6 & 24.975 & 0.1 & 0.05 & $0.749 \mathrm{~m}^{3}$ \\
\hline & Total & \multicolumn{4}{|c|}{-} & $125.358 \mathrm{~m}^{3}$ \\
\hline 3 & \multicolumn{5}{|c|}{ Reinforcing mild steel $420 \mathrm{MPa}$} & $1853629 \mathrm{~kg}$ \\
\hline 4 & \multicolumn{5}{|c|}{ Prestressing steel } & $2592270 \mathrm{~kg}$ \\
\hline
\end{tabular}

TABLE 8. COMPARISON OF MATERIALS FOR BOX AND T BEAM GIRDER BRIDGE

\begin{tabular}{|c|c|c|c|}
\hline $\begin{array}{c}\text { Dituminous wearing } \\
\text { surface }\end{array}$ & Box Girder & T-Beam & Remarks \\
\hline Concrete & $125.36 \mathrm{~m}^{2}$ & $208 \mathrm{~m}^{2}$ & Same Quantities \\
\hline Reinforcing steel & $18537 \mathrm{~kg}$ & $147.13 \mathrm{~m}^{3}$ & $\begin{array}{c}\text { Box girder require less concrete by 21.75 } \\
\mathrm{m}^{3}\end{array}$ \\
\hline Pre-stressing Cables & 4 @ $3=12 \mathrm{cables}$ & $5 @ 3=15 \mathrm{~kg}$ cables & Box girder requires excess steel by 1426 kg \\
\hline Pre-stressing Cables & $2539 \mathrm{~kg}$ & $3239 \mathrm{~kg}$ & $\begin{array}{c}\text { Box girder require less pre-stressing steel } \\
\text { by 646 kg. }\end{array}$ \\
\hline
\end{tabular}

TABLE 9. COMPARISON OF COST FOR BOX AND T BEAM GIRDER BRIDGE

\begin{tabular}{|c|c|c|c|c|}
\hline \multirow[t]{2}{*}{ Description } & Box Girder & $\begin{array}{l}\text { T-Beam } \\
\text { Girder }\end{array}$ & Cost Comparison & Remarks \\
\hline & Rs. Million & Rs. Million & Percentage $\%$ & Rs. Million \\
\hline $\begin{array}{c}\text { Bituminous } \\
\text { wearing } \\
\text { surface }\end{array}$ & 0.095 & 0.095 & 0 & Same Cost \\
\hline Concrete & 1.3330 & 1.5645 & $\begin{array}{l}17.37 \% \text { decrease in cost } \\
\text { for box girder }\end{array}$ & $\begin{array}{l}\text { Box girder require less amount by } \\
0.2315\end{array}$ \\
\hline $\begin{array}{l}\text { Reinforcing } \\
\text { Steel }\end{array}$ & 1.5571 & 1.4373 & $\begin{array}{l}8.33 \% \text { increase in cost for } \\
\text { box girder }\end{array}$ & $\begin{array}{l}\text { Box girder requires excess } \\
\text { amount by } 0.1198\end{array}$ \\
\hline $\begin{array}{l}\text { Pre-stressing } \\
\text { Cables }\end{array}$ & 0.9673 & 1.2340 & $\begin{array}{l}27.57 \% \text { decrease in cost } \\
\text { for box girder }\end{array}$ & $\begin{array}{l}\text { Box girder requires less amount } \\
\text { by } 0.2667\end{array}$ \\
\hline Total Cost & 3.9528 & 4.3312 & $\begin{array}{l}9.57 \% \text { decrease in cost in } \\
\text { case of box girder }\end{array}$ & Box girder is cheaper by 0.3784 \\
\hline
\end{tabular}


TABLE 7. BILL OF QUANTITIES FOR T BEAM BRIDGE

\begin{tabular}{|c|c|c|c|c|c|c|}
\hline No. & Description & No. & $\mathbf{L}(\mathbf{m})$ & B (m) & $\mathbf{H}(\mathbf{m})$ & Quantity \\
\hline 1 & Bituminous wearing surface & 1 & 24.975 & 8.4 & - & $209.79 \mathrm{~m}^{2}$ \\
\hline 2 & \multicolumn{6}{|c|}{ Concrete $21 \mathrm{MPa}$} \\
\hline \multirow{6}{*}{ a } & \multirow{5}{*}{ Barrier on both side of deck slab } & 2 & 24.957 & 0.22 & 0.865 & $9.506 \mathrm{~m}^{3}$ \\
\hline & & 2 & 24.957 & 0.55 & 0.535 & $0.668 \mathrm{~m}^{3}$ \\
\hline & & 2 & 24.957 & $0.18 / 2$ & 0.255 & $1.146 \mathrm{~m}^{3}$ \\
\hline & & 2 & 24.957 & 0.05 & 0.33 & $0.824 \mathrm{~m}^{3}$ \\
\hline & & 2 & 24.957 & 0.18 & 0.075 & $0.674 \mathrm{~m}^{3}$ \\
\hline & Total & - & - & - & - & $12.818 \mathrm{~m}^{3}$ \\
\hline $\mathrm{b}$ & Overhang $225 \mathrm{~mm}$ thick slab & 2 & 24.975 & 0.3 & 0.225 & $3.372 \mathrm{~m}^{3}$ \\
\hline $\mathrm{C}$ & Deck slab $200 \mathrm{~mm}$ thick & 1 & 24.925 & 8.7 & 0.2 & $43.457 \mathrm{~m}^{3}$ \\
\hline \multirow[t]{2}{*}{$\mathrm{d}$} & Diaphragm cast with slab & 12 & 1.025 & 0.3 & 1.35 & $4.982 \mathrm{~m}^{3}$ \\
\hline & Gross total & - & - & - & - & $64.629 \mathrm{~m}^{3}$ \\
\hline 3 & \multicolumn{6}{|c|}{ Concrete 35 MPa } \\
\hline $\mathrm{a}$ & $\begin{array}{c}\text { Diaphragm cast with girder }(\mathrm{mm}) \\
\text { Length }=(500+150) / 2=325 \\
\text { Width }=(300+600) / 2=933 \\
\text { Height }=(1125+860) / 2=993\end{array}$ & 30 & 0.335 & 0.45 & 0.993 & $4.357 \mathrm{~m}^{3}$ \\
\hline \multirow{12}{*}{ b } & Precast Girder & - & - & - & - & - \\
\hline & Top flange of Girder & 5 & 24.925 & 1.2 & 0.075 & $11.216 \mathrm{~m}^{3}$ \\
\hline & \multirow{3}{*}{ Top flange fillet } & 10 & 24.925 & 0.425 & $0.04 / 2$ & $10.212 \mathrm{~m}^{3}$ \\
\hline & & 10 & 24.925 & 0.075 & 0.04 & $0.748 \mathrm{~m}^{3}$ \\
\hline & & 10 & 24.925 & 0.075 & $0.075 / 2$ & $0.701 \mathrm{~m}^{3}$ \\
\hline & $\begin{array}{l}\text { Girder web height }=1600-200-75= \\
1325 \mathrm{~mm}\end{array}$ & 5 & 24.925 & 0.2 & 1.325 & $33.026 \mathrm{~m}^{3}$ \\
\hline & Bottom flange fillet & 10 & 24.925 & 0.15 & 0.15 & $5.608 \mathrm{~m}^{3}$ \\
\hline & Bottom flange & 5 & 24.925 & 0.5 & 0.2 & $12.463 \mathrm{~m}^{3}$ \\
\hline & End block & 20 & 1.2 & 0.15 & 0.976 & $3.514 \mathrm{~m}^{3}$ \\
\hline & Transition in end Block & 20 & 0.45 & $0.5 \times 0.15$ & 0.976 & $0.659 \mathrm{~m}^{3}$ \\
\hline & Total & - & - & - & - & $78.147 \mathrm{~m}^{3}$ \\
\hline & Gross total & - & - & - & - & $82.497 \mathrm{~m}^{3}$ \\
\hline 4 & Reinforcing mild steel $420 \mathrm{MPa}$ & - & - & - & - & $1711107 \mathrm{~kg}$ \\
\hline 5 & Prestressing steel & - & - & - & - & $323840 \mathrm{~kg}$ \\
\hline
\end{tabular}

\section{CONCLUSIONS}

The study summarizes the box girder as more suitable structure in terms of stability and economy as compared to $\mathrm{T}$ beam girder bridge superstructure. Allowable stress design method supports the adaptation of $\mathrm{T}$ beam girder for shorter span and box girder for longer spans. Contrary to this, strength design method reveals that box girder is better than $\mathrm{T}$ beam girder even for shorter span when it comes to structural and economic efficiency. The study also includes all the analysis and design aspects for both type of girders. Design shear and moment values were found more in case of box girder which added to its stiffness as well as confinement. It is concluded that box girder bridge requires lesser quantities of concrete and prestressing steel but it needs more quantity of reinforcing mild steel. Whereas, the total material cost is less as compared to $\mathrm{T}$ beam girder bridge superstructure. The overall comparison results depict that box girder is more suitable in terms of structural stability and cost effectiveness.

\section{ACKNOWLEDGMENT}

The authors are very thankful to Civil Engineering Department of University of Engineering and Technology, Lahore Pakistan and National Highway Mehran University Research Journal of Engineering and Technology, Vol. 39, No. 3, July 2020 [p-ISSN: 0254-7821, e-ISSN: 2413-7219] 
Authority, Islamabad Pakistan for providing support related to this study.

\section{REFERENCES}

[1] Robert, J. F. M., Michael, E.K, and John, E. B., "Strength and ductility of a three-span externally post-tensioned segmental box girder bridge model", Special Publication, Vol. No.120, pp. 315-338, 1990.

[2] Saxena, A., \& Maru, D. S., "Comparative study of the analysis and design of T-beam girder and box girder superstructure", International Journal of Research in Engineering \& Advanced Technology, Vol. 1, No. 2 , pp. 1-5, 2013.

[3] Phani, C., K., "Analysis and Design of prestressed box girder bridge", International journal of constructive research in civil engineering, Vol. 2, No. 2, pp. 1-10, 2016.

[4] Ahmed, A., \& Lokhande, R. B., "Comparative Analysis and Design of Tbeam and Box girders", International Research Journal of Engineering and Technology, Vol. 4, 2017.

[5] Choi, E., "Seismic analysis and retrofit of mid-America bridges", Doctoral dissertation, School of Civil and Environmental Engineering, Georgia Institute of Technology, Georgia, 2002.

[6] Malekly, H., Mousavi, S.M., and Hashemi.H., "A fuzzy integrated methodology for evaluating conceptual bridge design", Expert Systems with Applications, Vol. 37, No.7, pp. 4910-4920, 2010.

[7] Menn., "Materials and Actions in Prestressed Concrete Bridges", Birkhäuser Basel, pp. 6591, 1990.

[8] Misal, V. U, Gore, N.G., and Salunke, P.J., "Analysis and design of prestressed concrete girder", International Journal of Inventive Engineering and sciences (IJIES), Vol. 2, 2014.

[9] Kumar, R.A., and Krishna, B.V., "Design of Pre-Stressed Concrete T-Beams", International Journal of Scientific
Engineering and Research (IJSER), Vol. 2, No. 8, 2014.

[10] Venkateswara, K.R., and Kameswara, M.R., "Comparative Design of RCC and Prestressed Concrete Flyover along with RCC Abutments", International Journal for Scientific Research \& Development, Vol. 3, No. 6, 2015.

[11] Boatman, B., "Prestressed vs. Steel Beams Expected Service Life", Lansing. State of Michigan, Department of Transportation, 2010.

[12] Batikha, M., Al Ani, O., and Elhag, T., "The effect of span length and girder type on bridge costs", In MATEC Web of Conference, Vol. 120, pp. 08009, 2017.

[13] Jagtap, B.B.C., and Shahezad, M., "Comparative Study of Prestressed Concrete Girder and Steel Plate Girder for Roadway Over Bridge", International Journal of Scientific Research in Science, Engineering and Technology (IJSRSET), Vol. 2, No.1, pp 113-117, 2016.

[14] Fowler, J.R., Eng. P., Stofko, B., and Eng,P. "Precast options for bridge superstructure design", In Proceedings of Economic and Social Linkages Session, Annual Conference of the Transportation Association of Canada, 2017.

[15] Miles, J.C., and Moore, C.J., "An expert system for the conceptual design of bridges", Computers \& Structures, Vol. 40, No.1, pp. 101-105, 1991.

[16] Moore, C.J., and Miles, J.C., "The importance of detailed evaluation for KBS implementation in the engineering industry", Computing Systems in Engineering, Vol.. 2, No. 4, pp. 365-378, 1991.

[17] Naaman, A.E., "Prestressed concrete analysis and design fundamentals", pp. 360-364, New York: McGraw-Hill, 1982.

[18] Transportation Officials, "AASHTO LRFD Bridge Design Specifications: Customary US Units. American Association of state highway and transportation Officials", 1994.

[19] Libby, J.R., and Perkins, N.D., "Modern prestressed concrete highway bridge superstructures", design principles and 
construction methods, Grantville Pub. Co. 1976.

[20] Xanthakos., "Theory and design of bridges", John Wiley \& Sons, 1994.

[21] Hassan, M. I., Siddiqi, Z. A., and Ashraf, M., "Critical traffic loading for the design of prestressed concrete bridge", Mehran University Research Journal of Engineering and Technology, Vol. 28, No 3, pp. 303-316, 2009. 